\title{
MODEL PEMBELAJARAN TAUHID DI PONDOK PESANTREN MIFTAHUL HUDA MANONJAYA TASIKMALAYA
}

\author{
Ina Fauzianti, * \\ Edi Suresman, Abas Asyafah \\ Program Studi Ilmu Pendidikan Agama Islam, \\ Fakultas Pendidikan Ilmu Pengetahuan Sosial, Universitas Pendidikan Indonesia \\ *Email: efauziyanti@gmail.com
}

\begin{abstract}
ABSTRAK
Ilmu tauhid merupakan ilmu keislaman yang sangat penting diketahui oleh setiap muslim, karena ilmu ini paling penting dibanding ilmu keislaman lainnya. Ilmu ini membahas aqīdah dalam Islam yang merupakan inti dan dasar agama. Tetapi saat ini mayoritas umat Islam tidak menghayati tauhid dalam kehidupannya. Penelitian ini bertujuan untuk mengetahui dan memperoleh gambaran mengenai pembelajaran tauhid di pondok pesantren dengan memfokuskan pada tujuan, pendidik, peserta didik, materi, metode dan evaluasi. Metode yang digunakan dalam penelitian ini adalah metode deskriptif dengan pendekatan kualitatif. Data yang diolah berasal dari data wawancara, observasi dan dokumetasi. Hasil dari penelitian ini adalah Miftahul Huda yang di dirikan oleh KH. Choer Affandi pada tahun 1967 adalah pondok pesantren tradisional yang memiliki keunggulan dalam bidang agama Islam, salah satunya ilmu tauhid. Pesantren ini bertujuan mencetak santri agar menjadi Ulamā ${ }^{`} A l$ 'Ámilīn (Ulama yang mampu mengamalkan ilmunya), Imām Al Muttaqīn (Memimpin umat untuk bertakwa) dan Muttaqīn (Pribadi bertakwa). Pendidik yang lulusannya berasal dari Pondok Pesantren Miftahul Huda, memiliki peserta didik 2.652 santri putra dan putri dari berbagai daerah. Materi pembelajarannya terdapat delapan materi tauhid yang disampaikan sesuai dengan pembelajaran dan pengajaran Tauhid. Tercermin dalam tiga tahap yakni (1) pemberian bimbingan dan pengajaran; (2) pembiasaan; dan (3) pembentukan. Metode pembelajaran yang digunakan adalah metode klasik yakni ceramah, sorogan, dan bandongan. Hasil penelitian atau evaluasi pembelajaran yang diterapkan yakni evaluasi mingguan dan semesteran. Tolok ukur dalam keberhasilan pondok pesantren ini adalah para alumni yang mandiri dan dapat menciptakan masyarakat yang berbasis tauhid dengan mendirikan pondok pesantren.
\end{abstract}

Kata Kunci: Pembelajaran, Tauhid, Pondok Pesantren, dan Miftahul Huda 


\section{PENDAHULUAN}

Pada dasarnya setiap manusia mem-punyai fitrah kepercayaan terhadap adanya Zat Yang Maha Kuasa, yang dalam istilah agama disebut Tuhan. Fitrah manusia ter-sebut adalah fitrah beragama Tauhid yang dijadikan Allah SWT pada saat manusia itu di ciptakan(Asmuni, 1993, hlm. 21).

Tauhid adalah ajaran yang dibawa oleh setiap Nabi dan Rasūl, mulai dari nabi Adam as sampai Nabi Muhammad SAW. Senada dengan pendapat Asmuni (1993, hlm. 27) menyebutkan bahwa,"Akidah Islam sering disebut Tauhid ini sudah ada sejak zaman Nabi dan Rasūl, Nabi Adam telah membawa akidah keTauhid yang di berikan oleh Allah".

Mayoritas umat Islam saat ini tidak menghayati Tauhid dalam kehidupannya. Hal ini tercermin dari beberapa fenomena yang terjadi di masyarakat.Salah satu contohnya kasus bunuh diri.Badan Kesehatan Dunia, yaitu WHOSofwan (2014) mengabarkan bahwatingkat kematian aki-bat bunuh diri lebih tinggi dari pada korban perang dan bencana alam. Dalam sumber yang sama, Saxena mengemukkan bahwa dari 1,5 juta kematian tidak wajar setiap tahun di dunia, 800 ribu di antaranya adalah kasus bunuh diri. Menurutnya bunuh diri adalah penyebab kematian terbesar kedua untuk golongan usia 15-29 secara global.

Selain itu, sebagian masyarakat Indonesia terbiasa dengan ritual-ritual yang mengarah kepada syirik. Zaen (2013) menyebutkan contoh di antaranya adalah ritual yang dilaksanakan oleh penduduk kota Cilacap Jawa Tengah dengan mempersembahkan kepala kerbau bagi Nyai Roro Kidul, Sebagian orang menyembelih sapi untuk dipersembahkankepada 'penguasa'laut selatan agar berkenan membantu pe-nyelesaian proyek pembangunan jembatanyang menghubungkan antara kota Surabaya dan Madura.Kemudian Zaen (2013) menambahkan contoh lain, yaitu sebagian penduduk sekitar Rawa Pening Ambarawa Jawa Tengah melakukan ritual persembahan berupa ayam, nasi dan lainnya kepada penguasa danau kecil ini yang mereka sebut Mbah Baru Klinting, agar men-dapatkan kemudahan darinya dalam beker-ja, sebagai bentuk syukur kepadanya seka-ligus harapan memperoleh keberkahan da-rinya. Zaen (2013) juga menyebutkan con-toh lainnya, sebagian warga Yogyakarta melakukan persembahan berupa rokok, pi-sang, padi dan setetes darah ayam jika me-reka akan melangsungkan walimahan. Tu-juannya, agar jin penunggu desa mereka tidak mengusik jalannya acara. Dikenal de-ngan Uba Rampe.

Pendidikan memegang peranan penting dalam kelangsungan kehidupan suatu masyarakat dalam berbagai aspek, termasukTauhid. Menurut Asmuni (1993, hlm. v) ilmu Tauhid adalah salah satu ilmu keislaman yang sangat penting diketahui oleh setiap muslim, bahkan terpenting dibanding ilmu-ilmu keislaman yang lainnya, karena ilmu ini membahas masalah akidah dalam Islam yang merupakan inti dan dasar agama.Tanpa pengetahuan yang memadai dalam ilmu ini, seseorang akan mudah terjerumus ke dalam jurang kesesatan dan dosa yang tak terampunkan (syirik). Sehingga dapat diidentifikasikan bahwa fenomena yang dikemukakan di atas, dipengaruhi pula oleh pembelajaran.

Dengan menyadari pentingnya pembelajaran Tauhid, maka dari itu dianggap perlu meneliti model pembelajaran Tauhid di pondok pesantren, yang diharapkan dapat menjadi model pembelajaran Tauhid di lembaga lain. Dalam hal ini pondok pesantren yang akan diteliti adalah Pondok Pesantren Miftahul Huda Manonjaya.Hal ini juga berdasarkan hasil studi pendahulaun yang dilakukan oleh peneliti pada Pondok Pesantren Miftahul Huda Ma-nonjaya Tasikmalaya diperoleh info bah-wa: 
- Pondok Pesantren Miftahul Huda Manonjaya Tasikmalaya ini dihuni lebih dari 3.000 santri.

- Pondok Pesantren Miftahul Huda Manonjaya Tasikmalaya memiliki 1.000 lebih cabang Pesantren yang tersebar di Daerah Jawa dan Sumatera.

- Pondok Pesantren Miftahul Huda Manonjaya Tasikmalaya merupakan lembaga pembelajaran Islam yang dengan segala kelebihan dan kekurangannyaselalu mengupayakan agar para santrinya mampu berakhlaqul karimah dan mendapat ilmu yang bermanfa'at yang ditua-ngkan dalam tiga program Pesantren,yaitu; 1. Ulamā' $A l^{\prime} \bar{A}-$ milīn (Ulama yang mampu mengamalkan ilmunya), 2.Imām Al Muttaqīn (Memimpin ummat untuk bertaqwa), 3. Muttaqīn (Manusia yang bertahan dalam ketaqwaan.

- Pondok Pesantren Miftahul Huda Manonjaya Tasikmalaya mengembangkan sistem Salafiyyah menjadi pembelajaran yang semi formal, dimana perjenjangan, kurikulum pengajaran, silabus, dan sistem evaluasi disusun berdasarkan Jenjang Pem-belajaran (tingkat).

Berdasarkan uraian diatas, peneliti tertarik untuk mengkaji bagaimana model pembelajaran Tauhid di pondok pesantren, yang dikemas dalam judul: Model Pembelajaran Tauhid di Pondok Pesantren Miftahul Huda Manonjaya Tasikmalaya.

Perkataan Tauhid berasal dari bahasa Arab, masdar dari kata wahhadayuwahhidu. Secara etimologis, Tauhid berati keesaan. Maksudnya, itikad atau keyakinan bahwa Allah SWT adalah Esa; Tung-gal; Satu. Pengertian ini sejalan dengan pengertian Tauhid yang digunakan dalam bahasa Indonesia, yaitu "Keesaan Allah"; mentauhidkan berati "mengakui keesaan Allah; mengesakan Allah" (Asmuni, 1993, hlm. 1).Aspek pokok dalam ilmu Tauhid adalah keyakinan akan eksistensi AllahYang Maha Sempurna, Maha Kuasa, dan memiliki sifat-sifat kesempurnaan lainnya. Keyakinan demikian membawa seseorang kepada kepercayaan akan adanya malaikat, kitab- kitab Allah yang diturunkan Allah, nabinabi atau Rasūl-Rasūl, takdir, kehi-dupan sesudah mati, dan melahirkan ke-sadaran akan kewajibannyakepada Khalik (Pencipta) (Asmuni, 1993, hlm. 71).

Pendidikan agama Islam adalah upaya sadar dan terencana dalam menyiapkan peserta didik untuk mengenal, memahami, menghayati, hingga mengimani, bertakwa, dan berakhlak mulia dalam mengamalkan ajaran agama Islam dan sumber utamanya kitab suci al-qur 'ān dan Hadis, melalui kegiatan bimbingan, pengajaran, 1atihan, serta penggunaan pengalaman (Majid, 2012, hlm. 11)

Dalam bahasa Arab, kata kurikulum bisa diungkapkan dengan manhaj yang be-rati jalan yang dilalui manusia pada ber-bagai kehidupan, sedangkan kurikulum pendidikan (Manhaj al-Dirāsah) dalam ka-mus tarbiyah adalah seperangkat pere-canaan dan media yang dijadikan acuan oleh lembaga pembelajaran dalam mewu-judkan tujuantujuan pembelajaran (Majid, 2012, hlm. 34).

Belajar merupakan "Proses manusia untuk mencapai berbagai macam kom-petensi, keterampilan, dan sikap. Belajar dimulai sejak manusia lahir sampai akhir hayatMenurut (Wahyuni, 2012, hlm. 11) Sedangkan menurut Komalasari (2013, hlm. 1) belajar merupakan perubahan seseorang yang asalnya tidak tahu menjadi tahu merupakan hasil proses belajar.

Menurut Majid (2012, hlm. 127) istilah umum "model" diartikan sebagai kerangka konseptual yang digunakan sebagai pedoman dalam melakukan suatu kegiatan. Atas dasar pemikiran tersebut, maka yang dimaksud dengan "model belajar mengajar" adalah kerangka konseptual dan produser yang sistematik dalam mengorganisasikan pengalaman belajar un-tuk mencapai tujuan belajar tertentu, dan berfungsi sebagai pedoman bagi perancang pengajaran dan para guru dalam meren-canakan dan melaksanakan aktivitas belajar mengajar. 
Kholidah (2009, hlm. 150-156) menjelaskan prosedur pengembangan sistem instruksional dalam proses pembelajaran secara garis besar meliputi beberapa hal, yaitu:

1. Tujuan Pembelajaran

Benyamin S. Bloom (dalam Sujono, 2005: 49) berpendapat bahwa tujuan pembelajaran harus mengacu pada tiga aspek, yakni ranah proses berfikir (al-nahiyya alfik-riyah), ranah nilai atau sikap (alnahi-

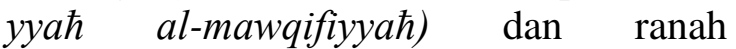
psikomotor (al-nahiyyah al-harakiyyah).

2. Pendidik

Guru (dalam bahasa jawa) adalah seorang yang harus "digugu" dan "ditiru" oleh semua siswanya. "Digugu" artinya segala se-suatu yang disampaikan olehnya senantiasa dipercaya dan diyakini sebagai kebenaran oleh semua siswa. Sebagai seorang yang di-gugu dan ditiru, seorang guru memiliki peran yang sangat luar biasa dominannya dalam penciptaan suasana religius di se-kolah bagi siswa.

3.Bahan (Materi) Pelajaran

Bahan pelajaran ini bersumber dari pokokpokok bahasan yang tercantum di dalam kurikulum. Kurikulum ini dibedakan menjadi dua macam, yakni kurikulum sebagai rencana (curriculum plan) dankurikulum fungsional (fungsioning curriculum) yaitu kurikulum yang dioperasikan di dalam kelas.

4.Metode Pembelajaran

Dalam penggunaan metode, hal penting yang perlu dipahami adalahbagaimana seorang pendidik dapat memahami hakikat metode dan relevansinya dengan tujuan utama pembelajaran. Selain itu bagaimana seorang pendidik dapat mendorong anak didiknya mau menggunakan nalar mereka dalam menelaah dan mempelajari gejala kehidupan, baik yang mencangkup diri me-reka sendiri dan alam sekitarnya.

5. Fasilitas dan Media Pembelajaran

Media pembelajaran adalah segala sesuatu yang dapat digunakan guru untuk menyalurkan pesan kepadasiswa sehingga dapat merangsangpikiran,perasaan, perhatian dan minat serta perhatian siswa sedemikan rupa sehinggamereka dapat memahami dengan baik dan benar apa yang disampaikan guru.

6.Evaluasi Hasil Belajar

Evaluasi penilaan merupakan serangkaian kegiatan untuk memperoleh, menganalisis dan menafsirkan data tentang proses dan hasil belajar peserta didik yang dilakukan secara sistematis dan berkesinambungan,sehingga menjadi informasi yang bermakna dalam pengambilan keputusan.

Secara terminologis pesantren didefinisikan sebagai lembaga pendidikan tradisional Islam untuk mempelajari, memahami, mendalami, menghayati, dan mengamalkan ajaran Islam dengan menekankan pentingnya moral kegamaan sebagai perilaku sehari-hari (Damopolii, 2011, hlm. 58).

\section{METODE}

Desain yang digunakan dalam penelitian ini adalah pendekatan kualitatif. Pendekatan ini lazim juga disebut naturalistik dimana penelitian dilakukan dengan orientasi pada kejadian-kejadian yang ber-sifat alami. Penelitian yang digunakan dal-am penelitian ini adalah penelitian deskriptif kualitatif. Menurut Mukhtar (2013, hlm. 10) penelitian deskriptif kualitatif ad-alah suatu pendekatan yang digunakan un-tuk menemukan pengetahuan terhadap sub-jek penelitian pada suatu saat tertentu.Partisipan atau subjek penelitian adalah yang berada dalam situasi sosial yang ditetapkan sebagai pemberi informasi dalam sebuah penelitian atau dikenal dengan informen. Dinamakan sebagai subjek penelitian, karena dalam penelitian kualitatif deskriptif penelitiannya dilakukan secara terpusat pada sudut orang yang diteliti (emik), baik mereka yang telah ditetapkan atau mereka yang dimintai informasi secara bergulir dan bergilir sehingga data mem-besar dan meluas (snow-ball), sampai titik jenuh data, artinya tidak ada lagi data yang mungkin dikumpulkan 
untuk menjawab da-n mendukung kebutuhan penelitian (Mukh-tar, 2013, hlm. 89).

Dalam penelitian ini, partisipan peneliti adalah kepada pimpinan pondok yaitu kiayi, bagian kurikulum, pendidik (us-tadz) dan peserta didik (santri) di Pondok Pesantren Miftahul Huda Tasikmalaya Ma-nonjaya.

Dalam penelitian ini, pengambilan data dilakukan pada natural setting (kondisi yang alamiah), sumber data primer dan teknik pengumpulan data lebih banyak pada observasi berperanserta, wawancara m-endalam dan dokumentasi (Sugiyono, 20-13, hlm. 308).

Wawancara adalah proses tanya jawab antara peneliti dengan subjek penelitian atau informen dalam satu situasi sosial. Wawancara menggunakan seperang-kat daftar pertanyaan yang sudah disiap-kan oleh peneliti yang akan dijawab me-lalui proses wawancara (Mukhtar, 2013, hlm. 118).

Observasi adalah proses keterlibatan peneliti dalam situasi sosial, kemudian dia mengungkapkan seluruh apa yang dilihat, dialami dan dirasakan langsung oleh peneliti (Mukhtar, 2013, hlm. 109). Do-kumentasi merupakan data pendukung yang dikumpulkan sebagai penguatan data observasi dan wawancara. Dokumentasi yang dimaksud adalah buku-buku yang relevan, laporan kegiatan, foto-foto dan datalain yang relevan (Mukhtar, 2013, hlm. 119).

\section{HASIL DAN PEMBAHASAN}

Miftahul Huda adalah pondok pesantren tradisional yang memiliki keunggulan dalam bidang agama Islam salah satunya yaitu ilmu Tauhid. Pondok Pesantren ini didirikan oleh KH. Choer Affandi pada tahun 1967. Nama pondok pesantren di buat langsung oleh Uwa Ajengan yaitu Miftahul Huda yang artinya "Kunci Petun-juk" dengan harapan pondok pesantren ini memberikan hidayah dan jalan untuk me-rubah umat menjadi lebih baik dengan belajar dan menuntut ilmu agama (DK.1). Pondok Pesantren Miftahul Huda Manon-jaya Tasikmalaya memiliki visi dan misi. Visi Pondok Pesantren Miftahul Huda yak-ni menjadikan Pondok Pesantren Miftahul Huda sebagai pusat pembelajaran agama Islam yang unggulan secara nasional dalam rangka penghayatan atas ke esaan Allah SWT. Adapun visi diatas diturunkan men-jadi misi-misi sebagai berikut: mencetak santri menjadi (a) Ulamā' Al 'Ámilīn (Ula-ma yang mampu mengamalkan ilmunya), (b) Imām Al Muttaqin (Memimpin umat untuk bertakwa), dan (c) Muttaqīn (Pribadi yang bertakwa) (Dok.2).

Tujuan kurikulum pembelajaran tauhid pesantren adalah untuk mencapai hasil maksimal dalam mencapai misi pondok pesantren yaitu: mencetak santri untuk mejadi ulamā' al 'ámilin (Ulama yang mampu me-ngamalkan Ilmunya) yaitu tercapainya tujuan habl minal'alām (hubungan dengan alam), imām al muttaqīn (Memimpin umat untuk bertakwa) yaitu tercapainya tujuan $h a b l$ minal nās (hubungan dengan manu-sia), dan muttaqīn (Pribadi yang bertaqwa) yaitu tercapainya tujuan habl minAllāh(hubungan dengan Allah).

Pondok Pesantren Miftahul Huda masih menggunakan implementasi kurikulum tradisonal. Pendapat tersebut sejalan

dengan menurut pendapat Arifin (2014, hlm. 3) pengertian kurikulum tradisonal yaitu (a) kurikulum terdiri atas sejumlah mata pelajaran, (b) mata pelajaran adalah kum-pulan warisan budaya dan pengalaman-pengalaman masa lampau yang mengan-dung nilai-nilai positif untuk disampaikan kepada generasi muda, (c) mata pelajaran tersebut harus mewakili semua aspek kehi-dupan dan semua domain hasil belajar se-suai dengan standar ko-mpetensi dasar ya-ng telah ditetapkan, (d) peserta didik harus mempelajari dan menguasai seluruh mata pelajaran, (f) mata pelajaran tersebut hanya dipelajari di sekolah sekolah secara 
ter-pisah-pisah, dan (g) tujuan akhir kurikulum adalah untuk memperoleh izasah.

Sejalan dengan Program Pondok Pesantren Miftahul Huda dalam mencapai visi dan misi pondok, maka pondok pesantren ini memiliki pendidik yang unggul dalam bidang agama Islam, salah satunya unggul dalam bidang Tauhid. Karena pe-ngajar di pondok pesantren ini memiliki dua orang pengajar didalam kelas yaitu pe-ngajar pokok dan muharik yang menjadi guru sekaligus pembimbing peserta didik selama dikelas. Pengajar pokok berasal dari keluarga pondok pesantren yaitu para de-wan kiayi, anwar muda, dan cucu dewan kiyai, kemudian muharik adalah santri yang sedang mejalani masa pengabdian di Pondok Pesantren Miftahul Huda (WU.4, WU.5, WA.2, dan WU.3). Pengajar atau guru di pondok pesantren Miftahul Huda memiliki empat fungsi yang diberikan oleh Uwa Ajengan yaitu sebagai Mu'alim (Mengajarkan atau memberikan wawasan keilmuan kepada santri), Mu'ādib(Mendidik santri untuk berakhlak), Murrabī (Menga-tur, mengurus sampai sendi-sendi masya-rakat untuk menyerukan Islam) dan Muja-hīd (Memperjuangkan ajaran Islam).

Keadaan santri di Pondok

Pesantren Miftahul Huda berjumlah 2.652 santri putra

dan putri yang berasal dari berbagai daerah, mereka semua mempunyai tujuan ingin belajar ilmu agama Islam sehingga pondokpesantren tidak melihat dari segi latar-belakang dan batasan umur peserta didik.

Materi pembelajaran Tauhid di Pondok Pesantren Miftahul Huda sesuai dengan teori aspek pokok dalam ilmu Tauh-id, yaitu keyakinan akan eksistensi Allah Yang Maha Sempurna, Maha Kuasa, dan memiliki sifat-sifat kesempurnaan lainnya. Keyakinan demikian membawa seseorang kepada kepercayaan akan adanya malaikat, kitab-kitab Allah yang diturunkan Allah, nabi-nabi atau Rasūl-
Rasūl, takdir, kehidu-pan sesudah mati, dan melahirkan kesa-daran akan kewajibannyakepada Khalik (Pencipta) (Asmuni, 1993, hlm. 71). Deng-an itu, Asmuni (1993, hal. 71) menjelaskan lagi, ruang lingkup pembahasan dalam il-mu Tauhid yang pokok adalah sebagai berikut:

1.Hal-hal yang berhubungan dengan Allah SWT atau yang sering disebut dengan istilah mab'dā. Dalam bagian ini termasuk masalah takdir. Tercantum dalam materi $a$ -

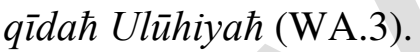

2.Hal-hal yang berhubungan dengan utusan Allah sebagai perantara antara manusia dan Allah. Meliputi: Malaikat, Nabi/Rasūl, dan kitab-kitab suci. Tercan-tum dalam

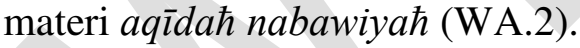

3.Hal-hal yang berhubungan dengan hari yang akan datang, atau disebut pula $m a ' \bar{a} d$, meliputi: surga, neraka dan sebagainya. Te-rcantum dalam materi aqīdah sam'iyaћ (WU.5).

Pondok Pesantren Miftahul Huda memiliki keunggulan dalam mata pelajaran Tauhidnya, di pondok pesantren ini ilmu Tauhid dikaji dan diperdalam oleh santri saat pembelajaran dikelas. Menurut WU.4, materi pembelajaran Tauhid di pondok pesantren ini, terdapat 8 materi, yaitu tentang syahadatain, tijān addaruri $\bar{l}$, majmuatul aqīdaћ, kifāyatulawwām, jauhartauhīd, khalidatul bari-yah, kitab

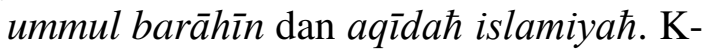
edelapan materi tersebut ter-pecahkan lagi berdasarkan tingkatannya (Wawancara, 5 April 2015).

Metode pembelajaran Tauhid di Pondok Pesantren Miftahul Huda menggunakan metode pembelajaran klasik sesuai dengan teori metode pembelajaran agama Islam yang berjalan saat ini masih sebatas transper nilai dengan pendekatan hapalan. Diungkapkan oleh Mastuhu (2002) dalam buku Kholidah $(2009$, hlm. 32) menyatakan bahwa:

Metode pembelajaran yang berlaku saat ini masih bersifat klasik, dalam arti mewariskan sejumlah materi ajaran agama yang diyakini benar untuk disampaikan 
kepada anak didik tanpamemberikan kesempatan kepada mereka agar menyikapi materi-materi tersebut secara kritis, mengoreksi, mengevaluasi dan mengomentarinya.Metode pembelajaran klasik yang digunakan oleh Pondok Pesantren Miftahul Huda (OK.1,OK.2, dan OK.3)sesuai deng-an teori menurut Kholidah (2009, hlm. 49) ada beberapa metode pengajaran Pendidikan Agama Islam adalah seba-gai berikut:

\section{Metode Ceramah}

Merupakan metode pembelajaran yang sangat populer di kalangan para pendidik agama Islam. Metode ini menekankan pada pemberan dan penyampaian informasi ke-pada anak didik. Dalam pelaksanaannya, pendidik bisa menyampaikan materi agama dengan cara persuasif, memberikan mo-tivasi, baik berupa kisah atau memberikan (amșal) sehingga peserta didik dapat men-cerna dengan baik (Kholidah, 2009, hlm. 49).

\section{Metode Sorogan}

Metode sorogan merupakan suatu metode yang ditempuh dengan cara guru menyampaikan pelajaran kepada santri secara individual, biasanya di samping pesantren juga dilangsungkan di langgar, masjid atau di rumah-rumah. Penyampaian pembelajaran santri secara ber-giliran ini biasanya dipraktekkan pada santri yang jumlahnya sedikit. Melalui sorogan, perkembangan intelektual santri dapat ditangkap secara utuh (Qomar 2002, hlm. 124).

\section{Metode Wetonan atau Bandongan}

Adalah metode yang paling utama di pesantren. Zamarkasyari Dhofier menerangkan bawa metode wetonan (bando-ngan) ialah suatu metode dengan cara guru membaca, menerjemahkan, menerangkan dan mengulas buku-buku Islam dalam ba-hasa Arab sedangkan sekelompok santrinya mendengarkannya. Mereka memperhatikan bukunya sendiri dan membuat catatan-catatan (baik arti maupun keterangan) ten-tang kata-kata atau buah pikiran yang sulit (Qomar, 2002, hlm. 143).

Evaluasi pembelajaran Tauhid dilakukan untuk mengukur sejauh mana pendidikan Tauhid ini berhasil di Pondok Pesantren Miftahul Huda. Pendapat ini sejalan dengan pendapat Nata (2005, hlm. 186), bahwa evaluasi pendidikan memiliki kedudukan yang sangat strategis, karena hasil dari kegiatan evaluasi dapat digunakan sebagai input untuk melakukan perbaikan kegiatan pembelajaran.

Untuk mengetahui sejauhmana keberhasilan pembelajaran Tauhid di Pondok Pesantren Miftahul Huda yaitu mencapai bobot nilai empat. Kemudian, dilihat dari hasil nilai pembelajaran Tauhid sejauh ini sejauh ini tujuan pembelajarannya telah tercapai.

Tolak ukur keberhasilan evaluasi pembelajaran Tauhid ini adalah keberhasilan para alumni yang mandiri dan menciptakan masyarakat yang berbasis Tauhid dengan mendirikan pondok pesantren (DK2). Berhasil memiliki 1000 lebih cabang Pesantren yang tersebar di Daerah Jawa dan Sumatera (DK.1).

\section{KESIMPULAN}

Miftahul Huda adalah pondok pesantren tradisional yang memiliki keunggulan dalam bidang agama Islam salah satunya yaitu ilmu Tauhid. Pondok Pesantren ini didirikan oleh KH. Choer Affandi pada tahun 1967.Visi Pondok Pesantren Miftahul Huda sebagai pusat pembelajaran agama Islam yang unggulan secara nasional dalam rangka penghayatan atas keesaan Allah SWT. Adapun visi diatas diturunkan menjadi misi-misi sebagai berikut: men-cetak santri menjadi (a) Ulamā ${ }^{\top}$ Al 'Ámilīn (Ulama yang mampu mengamalkan ilmu-0nya), (b) $\operatorname{Imām} A l$ Muttaqin(Memimpin umat untuk bertakwa), dan (c) Muttaqīn (Pribadi yang bertakwa) (Dok.2).

Pembelajaran Tauhid di Pondok Pesantren Miftahul Huda memiliki tujuan pembelajaran yaitu: mempunyai capaian 
tujuan habl minallāh (hubungan dengan Allah), habl minal nās (hubungan manusia) dan habl minal'alām (Hubungan dengan alam)yang masih menggunakan kurikulum tradisional.

Pendidik atau guru pondok pesantren Miftahul Huda lulusanya berasal dari Pondok Pesantren Miftahul Huda yang unggul dalam bidang agama Islam, salah satunya unggul dalam bidang Tauhid.

Pondok pesantren ini memiliki dua orang pengajar didalam kelas yaitu pengajar pokok dan muharik yang menjadi guru selama dikelas.

Santri di Pondok Pesantren Miftahul Huda berjumlah 2.652 santri putra dan putri yang berasal dari berbagai daerah.

Materi yang disampaikan dalam pe-mbelajaran Tauhid di pondok ini yaitu te-ntang syahadatain, tijān ad-addarurī, maj-muatul aqīdaћ, kifāyatul awam, jauhar Tauhid, khalidatul bahiyaћ, kitab

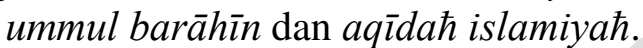

Metode pembelajaran klasik yang digunakan oleh Pondok Pesantren Miftahul Huda yaitu metode ceramah, metode soro-gan dan metode wetonan atau bandongan.Evaluasi yang di terapkan di Pondok Pesa-ntren Miftahul Huda yaitu evaluasi ming-guan dan evaluasi Semesteran.

Indikator keberhasilan evaluasi pembelajaran Tauhid ini adalah keberhasilan para alumni yang menciptakan masyarakat yang berbasis Tauhid dengan mendirikan pondok pesantren dan berhasil memiliki 1000 lebih cabang Pesantren yang tersebar di Daerah Jawa dan Sumatera.

\section{REFERENSI}

Arifan, F. A. (2014, Mei 8). Evaluasi Pembelajaran di Madrasah dan Pesantren. Retrieved Maret 10, 2015, from Edukasi Kompasiana: http://edukasi.kompasiana.com

Asmuni, D. H. (1993). Ilmu Tauhid. Jakarta: PT RajaGrafindo Persada.
Dhofier, Z. (2011). Tradisi Pesantren . Jakarta Barat: LP3ES.

Kholidah, A. M. (2009). Metode dan Teknik Pembelajaran Pembelajaran Agama Islam. Bandung: PT Refrika Aditama.

Komalasari, K. (2013). Pembelajaran Kontekstual Konsep dan Aplikasi. Bandung: Refika Aditama.

Majid, A. (2012). Belajar dan Pembelajaran Pendiidkan Agama Islam. Bandung: ROSDA.

Nasional, D. P. (2008). Kamus Besar Bahasa Indonesia. Jakarta: Gramedia Pustaka Utama.

Nata, A. (2005). Filsafat Pendidikan Islam. Jakarta: Gaya Media Pratama.

Nata, A. (2010). Ilmu Pendidikan Islam. Jakarta: Kencana.

Sofwan, R. (2014, September 5). Laporan WHO: Bunuh Diri Terjadi 40 Detik. Dipetik Februari 13, 2015, dari CNNINDONESIA: http://www.cnnindonesia.com/inter nasional/20140905130645-1342544/bunuh-diri-terjadi-tiap-40detik/\#

Sugiyono. (2013). Metode Penelitian Pendidikan. Bandung: Alfabeta.

Suresman, E. (2011). Dirosah Aqidah Asasiyah Wal Milal. Bandung: RIZKI PRES.

Uno, H. B. (2014). Model Pembelajaran Menciptakan Proses Belajar Mengajar yang Kreatif dan Efektif. Jakarta: Bumi Aksara.

Zaen, A. (2013, Maret 16). Belajar Islam. Retrieved Februari 13, 2015, from Ritual-Ritual Persembahan Syirik di Sekitar Kita: https://msulhan.wordpress.com/2013/03/16/ritualritual-persembahan-syirikdisekitar-kita/ 